\title{
Late Glacial to Holocene environments in the present-day coldest region of the Northern Hemisphere inferred from a pollen record of Lake Billyakh, Verkhoyansk Mts, NE Siberia
}

\author{
S. Müller ${ }^{1}$, P. E. Tarasov ${ }^{1}$, A. A. Andreev ${ }^{2}$, and B. Diekmann ${ }^{2}$ \\ ${ }^{1}$ Freie Universität Berlin, Geological Sciences, Palaeontology Section, Berlin, Germany \\ ${ }^{2}$ Alfred Wegener Institute for Polar and Marine Research, Research Unit Potsdam, Germany \\ Received: 24 September 2008 - Published in Clim. Past Discuss.: 26 November 2008 \\ Revised: 12 February 2009 - Accepted: 19 February 2009 - Published: 6 March 2009
}

\begin{abstract}
In this study, a radiocarbon-dated pollen record from Lake Billyakh $\left(65^{\circ} 17^{\prime} \mathrm{N}, 126^{\circ} 47^{\prime} \mathrm{E}\right.$; $340 \mathrm{~m}$ a.s.l.) in the Verkhoyansk Mountains was used to reconstruct vegetation and climate change since about $15 \mathrm{kyr}$ BP. The pollen record and pollen-based biome reconstruction suggest that open cool steppe (STEP) and grass and sedge tundra (TUND) communities with Poaceae, Cyperaceae, Artemisia, Chenopodiaceae, Caryophyllaceae and Selaginella rupestris dominated the area from 15 to $13.5 \mathrm{kyr}$ BP. On the other hand, the constant presence of Larix pollen in quantities comparable to today's values points to the constant presence of boreal deciduous conifer (CLDE) trees in the regional vegetation during the Late Glacial. A major spread of shrub tundra communities, including birch (Betula sect. Nanae), alder (Duschekia fruticosa) and willow (Salix) species, is dated to 13.5-12.7 kyr BP, indicating a noticeable increase in precipitation toward the end of the Last Glaciation, particularly during the Bølling-Allerød Interstadial. Between 12.7 and 11.4 kyr BP pollen percentages of herbaceous taxa rapidly increased, whereas shrub taxa percentages decreased, suggesting strengthening of the steppe communities associated with the relatively cold and dry Younger Dryas Stadial. However, the pollen data in hand indicate that Younger Dryas climate was less severe than the climate during the earlier interval from 15 to $13.5 \mathrm{kyr}$ BP. The onset of the Holocene is marked in the pollen record by the highest values of shrub and lowest values of herbaceous taxa, suggesting a return of warmer and wetter conditions after $11.4 \mathrm{kyr}$ BP. Percentages of tree taxa increase gradually and reach maximum values after 7 kyr BP, reflecting the spread of boreal cold deciduous and
\end{abstract}

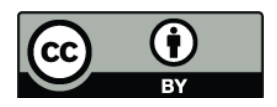

Correspondence to: S. Müller (stefanie.mueller@awi.de) taiga forests in the region. An interval between 7 and $2 \mathrm{kyr}$ $\mathrm{BP}$ is noticeable for the highest percentages of Scots pine (Pinus subgen. Diploxylon), spruce (Picea) and fir (Abies) pollen, indicating mid-Holocene spread of boreal forest communities in response to climate amelioration and degradation of the permafrost layer.

\section{Introduction}

Global and regional climate models predict noticeable 21st century climate warming, which is expected to be most pronounced in high latitudes of the Northern Hemisphere (ACIA, 2004). In particular, predicted winter warming is expected to exceed the global annual average, causing great reduction of sea-ice cover and significant degradation of permafrost (French and Williams, 2007). All these changes will most certainly destabilize fragile Arctic vegetation and environments and might in turn influence global atmospheric circulation and climate. The International Council for Science (ICSU, 2004) agreed to establish the International Polar Year (IPY) in 2007-2008 in order to "start a new era in polar science; to intensify interdisciplinary research programs focussing on the Arctic and the Antarctic regions and to understand better the strong links these regions have with the rest of the globe".

The investigation presented in this paper is part of the IPY project 106 "Lake Records of Late Quaternary Climate Variability in northeastern Siberia" and the German Research Foundation project "Late Quaternary environmental history of interstadial and interglacial periods in the Arctic reconstructed from bioindicators in permafrost sequences in $\mathrm{NE}$ Siberia". Both projects focus on generating high-resolution

Published by Copernicus Publications on behalf of the European Geosciences Union. 


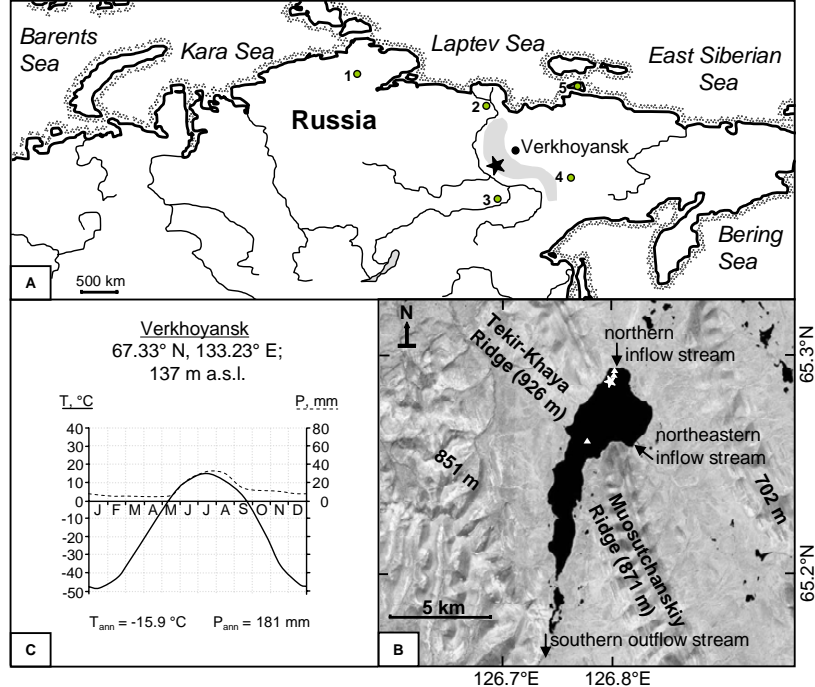

Fig. 1. (A) Map of northeastern Eurasia, in which shaded area represents the Verkhoyansk Mountains and green points mark sites mentioned in the discussion: 1 - Levinson-Lessing Lake, 2 - Lake Dolgoe, 3 - Lake Chabada, 4 - Smorodinovoye Lake, 5 - Bol'shoy Lyakhovsky Island. (B) Enlarged map showing the Lake Billyakh $\left(65^{\circ} 27^{\prime} \mathrm{N}, 126^{\circ} 47^{\prime} \mathrm{E} ; 340 \mathrm{~m}\right.$ a.s.1.) study area and location of the analysed core PG1756 (a star) and other cores taken during the field campaign in 2005 (triangles). (C) Chart showing mean monthly temperature and precipitation at the Verkhoyansk meteorological observatory (Rivas-Martínez, 1996-2004).

vegetation and climate proxy records from the lacustrine sediments along a north-south transect from Yakutia (Sakha) Republic of Russia - the region of Eurasia, which is known for its climate extremes, with the Verkhoyansk Mountain Range being the coldest area in the Northern Hemisphere (Shahgedanova et al., 2002). The coastal and mountain areas are dominated by tundra vegetation, whereas cold deciduous forest and taiga vegetation are widespread in central and southern Yakutia, where mean July temperatures reach 15 $19^{\circ} \mathrm{C}$ (Alpat'ev et al., 1976). Because of its relatively dry continental climate, this part of Siberia did not experience extensive Late Pleistocene glaciation (Stauch, 2006; Popp et al., 2007; Stauch et al., 2007) in contrast to other arctic regions, including northern parts of western Siberia, Europe and North America which were covered by large ice sheets.

Since the second half of the last century peat and lake sediments from the region have been studied by means of pollen analysis, and results were used to reconstruct past vegetation and climate conditions of the Late Quaternary (e.g. Khotinsky, 1977; Velichko et al., 1997). However, detailed reconstructions of the vegetation and climate history were limited by the shortage of reliable radiocarbon data. During the last decade, strengthening of international co-operation in the Arctic facilitated access to several highresolution and adequately dated pollen records from north- eastern Eurasia covering the Late Pleistocene and Holocene periods (e.g. Andreev and Klimanov, 1989; Peterson, 1993; Texier et al., 1997). These records were then used for quantitative vegetation reconstruction in the global vegetation mapping BIOME6000 project (e.g. Tarasov et al., 1998; Prentice et al., 2000). Despite a general progress in the environmental studies of northeastern Eurasia, the Verkhoyansk Mountain area is still poorly investigated.

This paper fills the gap in the earlier pollen studies of the region and presents a high resolution pollen record from Lake Billyakh, located in the central part of the Verkhoyansk Mountain region (Fig. 1). The record spans the last $15 \mathrm{kyr}$ ( $1 \mathrm{kyr}=1000 \mathrm{cal}$. yr) as suggested by the age model, which is based on seven radiocarbon dates. Both qualitative interpretation of the pollen data and quantitative pollen-based biome reconstruction are used to interpret changes in regional vegetation and climate during the Late Glacial-Holocene time interval. We then discuss these results together with the published results of earlier palaeoenvironmental studies from northeastern Eurasia.

\section{Regional setting}

The Verkhoyansk Mountain Range (2389 m a.s.l.) is one of the most prominent mountain chains of northeastern Eurasia. It extends along $128^{\circ} \mathrm{E}$ longitude east of the Lena River for $900 \mathrm{~km}$ from the Laptev Sea coast to about $64^{\circ} \mathrm{N}$. The southern latitudinal section extends north of the Aldan River (Lena's right tributary) for $350 \mathrm{~km}$ between $128^{\circ}$ and $136^{\circ} \mathrm{E}$ (Alpat'ev et al., 1976; Shahgedanova et al., 2002).

Lake Billyakh $\left(65^{\circ} 17^{\prime} \mathrm{N}, 126^{\circ} 47^{\prime} \mathrm{E}\right.$; altitude $\left.340 \mathrm{~m}\right)$ is situated in the central part of the Verkhoyansk Mountains (Fig. 1a), occupying a longitudinal depression between the Tekir-Khaya Ridge and the Muosutchanskiy Ridge (Fig. 1b). The lake extends for about $11 \mathrm{~km}$ from north to south and for about $3 \mathrm{~km}$ from west to east. It has an average water depth of $8 \mathrm{~m}$ and a maximum depth of about $25 \mathrm{~m}$. The lake is fed by direct precipitation and by several small creeks and streams flowing from the surrounding mountain slopes (Fig. 1b). An outflow stream flows from the southern part of the lake towards the Lena River.

The region is characterised by the world's most extreme continental climate. Verkhoyansk $\left(67^{\circ} 33^{\prime} \mathrm{N}, 133^{\circ} 33^{\prime} \mathrm{E}\right.$; 137 m a.s.l.) is known as the Northern Hemisphere's Pole of Cold. There the instrumentally measured minimum and maximum temperatures reached $-67.8^{\circ} \mathrm{C}$ and $39^{\circ} \mathrm{C}$, respectively. The mean values for January and July temperatures are $-48.6^{\circ} \mathrm{C}$ and $13.9^{\circ} \mathrm{C}$ and annual precipitation reaches $181 \mathrm{~mm}$ (Rivas-Martínez, 1996-2004; Fig. 1c). The very cold and long winters together with short summers cause the large thickness of continuously frozen ground reaching 400 $900 \mathrm{~m}$ (Gavrilova, 1993).

Floristically the study area belongs to the boreal forest zone. Northern larch (Larix dahurica) forest with Scots 
pine (Pinus sylvestris), birch trees (Betula platyphylla) and shrubs (B. middendorfii, B. fruticosa, Duschekia fruticosa) dominate the vegetation. In the understorey, heath (Ericales) species are very abundant, including Vaccinium vitis-idaea, V. uliginosum, Arctous alpina, Ledum palustre, Cassiope sp., Empetrum nigrum together with members of Rosaceae family (Sanguisorba officinalis, Rosa sp., Spiraea sp.), grasses (Poaceae) and sedges (Cyperaceae) (Walter, 1974). Common mosses are Polytrichum sp., Dicranum sp., Sphagnum sp. and lichens Cladonia sp., Cetraria sp. (Walter, 1974). Above approximately $450 \mathrm{~m}$ a.s.l., the woodland is replaced by arctic-alpine tundra and dwarf shrub tundra communities with Pinus pumila, Betula nana, Empetrum sp., Vaccinium vitis-idaea, V. uliginosum and Ledum sp.

\section{Field and laboratory methods}

\subsection{Coring and lithology}

Sediment coring with an UWITEC piston corer system was performed at one site in the central profundal basin of the lake and at three other sites located near the northern shore (Diekmann et al., 2007; Fig. 1b). A total of $35 \mathrm{~m}$ of sediment were recovered from the four sites and transported to Germany for further analyses.

The $660 \mathrm{~cm}$ long core PG1756 described in the present study was recovered from a small subbasin about $800 \mathrm{~m}$ off the northern shore, from $7.9 \mathrm{~m}$ water depth. The core consists of homogenous dark greenish grey sandy silt $(0-145 \mathrm{~cm})$, homogenous dark greenish grey clayey silt $(145-374 \mathrm{~cm})$, finely stratified dark greenish grey sandy silt $(374-429 \mathrm{~cm})$, greyish silt $(429-450 \mathrm{~cm})$ and basal dark greyish sand below $450 \mathrm{~cm}$ (Fig. 2a).

\subsection{Pollen analysis}

The core material stored at AWI (Potsdam) was sampled there for pollen analysis. Samples were taken as $1 \mathrm{~cm}$ slices every $5 \mathrm{~cm}$, yielding an average temporal resolution of 190 years. Further chemical treatment of the samples and pollen analysis were performed in the pollen laboratory at FU Berlin. Pollen extraction from the samples consisting of $1.5 \mathrm{~g}$ sediment was performed according to standard procedures, including $7-\mu \mathrm{m}$ ultrasonic fine-sieving, HF treatment and acetolysis (Fægri et al., 1989; Cwynar et al., 1979). One tablet of Lycopodium marker spores was added to each sample for calculating total pollen and spore concentrations (Stockmarr, 1971). Water-free glycerol was used for sample storage and preparation of the microscopic slides. Pollen and spores were identified at magnifications of $400 \times$ and $1000 \times$, with the aid of published keys (Kupriyanova et al., 1972, 1978; Bobrov et al., 1983; Reille, 1992, 1995, 1998; Beug, 2004) and a modern pollen reference collection at FU Berlin.
Preservation of pollen and spores was very good, and corroded grains were found mainly in the lower part of the core below $419 \mathrm{~cm}$, in sediments with a higher sand content. Bisaccate pollen of Pinus and Picea were frequently broken. The pollen and spore content of the samples was sufficiently high to allow counting of a minimum of 500 terrestrial pollen grains per sample. In total, 71 pollen and spore taxa were identified in the PG1756 core. In this study pollen of $\mathrm{Pi}$ nus was separated into two morphological types, e.g. $P$. subgen. Diploxylon and P. subgen. Haploxylon. In the study area these two pollen types are produced by $P$. sylvestris (tree pine) and P. pumila (shrub pine), respectively. Betula pollen was also divided into two morphological types: $B$. sect. Nanae (shrub birch) and B. sect. Albae (tree birch). The contribution of re-deposited pollen and spores was unimportant, suggesting non-disturbed pollen assemblages.

Calculated pollen percentages refer to the total sum of terrestrial pollen, which does not include pollen of aquatic plants, spores of pteridophytes and mosses, algae and redeposited pollen and spore grains. For these taxa, percentages were calculated using the total terrestrial pollen sum plus the sum of palynomorphs in the respective group. The Tilia/Tilia-Graph/TGView software (Grimm, 1993, 2004) was used for calculating pollen percentages and for drawing the pollen percentage diagram. The local pollen zones in the diagram were divided using CONISS (Grimm, 2004) and numbered from the top to the bottom of the core to allow future comparison with longer pollen sequences from Lake Billyakh.

\subsection{Quantitative technique for vegetation reconstruction and palaeoclimatic interpretation}

Pollen-based vegetation reconstruction was performed using the quantitative method of biome reconstruction first described by Prentice et al. (1996) and adapted for reconstruction of northern Eurasian vegetation types (biomes) by Tarasov et al. (1998). The approach allows the objective assignment of pollen taxa to plant functional types (PFTs) and to biomes on the basis of the modern ecology, bioclimatic tolerance and geographical distribution of pollen producing plants. The biome reconstruction method was successfully tested using an extensive surface pollen data set from northern Eurasia and applied to mid-Holocene and Last Glacial Maximum (LGM) pollen data (Tarasov et al., 1999a, 1999b). The results of biome reconstruction proved to be useful for the objective interpretation of the Late Quaternary vegetation and climate dynamics at global, regional and local scales and for data-model comparison (Texier et al., 1997; Prentice et al., 1996; Prentice et al., 2000; Tarasov et al., 2005).

In this study all identified terrestrial pollen taxa were initially used for the construction of the biome-PFT-taxon matrix. Among them only 28 taxa, which exceed the universal threshold of $0.5 \%$ suggested by Prentice et al. (1996) and used by Tarasov et al. (1998), influenced biome 
Table 1. Terrestrial pollen taxa identified in the core PG1756 from Lake Billyakh and their attribution to the vegetation types/biomes characteristic for northern Asia. Taxa whose percentages in the pollen spectra do not exceed 0.5\% (threshold suggested by Prentice et al., 1996) and do not influence results of biome reconstruction are indicated with an asterisk.

\begin{tabular}{|c|c|}
\hline Biome & Terrestrial pollen taxa \\
\hline TUND/Tundra & $\begin{array}{l}\text { Duschekia fruticosa, Betula sect. Nanae, Cyperaceae, Ericales ind., E. Empetrum, E. Vaccinium, Pa- } \\
\text { paveraceae, Poaceae, Polemonium*, Polygonaceae ind., Polygonum bistorta, P. viviparum, Rumex*, } \\
\text { R. aquatilis*, Salix, Saxifragaceae, Scrophulariaceae ind., S. Pedicularis, Valeriana }\end{array}$ \\
\hline CLDE/Cold deciduous forest & $\begin{array}{l}\text { Betula sect. Albae, Ericales ind., E. Empetrum, E. Vaccinium, Juniperus*, Larix, Pinus subgen. } \\
\text { Diploxylon, Pinus subgen. Haploxylon, Salix }\end{array}$ \\
\hline TAIG/Taiga & $\begin{array}{l}\text { Abies, Betula sect. Albae, Ericales ind., E. Empetrum, E. Vaccinium, Juniperus*, Larix, Picea, Pinus } \\
\text { subgen. Diploxylon, Pinus subgen. Haploxylon, Salix }\end{array}$ \\
\hline $\mathrm{COCO} / \mathrm{Cool}$ coniferous forest & $\begin{array}{l}\text { Abies, Betula sect. Albae, Ericales ind., E. Empetrum, E. Vaccinium, Juniperus*, Larix, Picea, Pinus } \\
\text { subgen. Diploxylon, Pinus subgen. Haploxylon, Salix }\end{array}$ \\
\hline STEP/Steppe & $\begin{array}{l}\text { Apiaceae*, Armeria, Artemisia, Asteraceae subfam. Asterioideae ind., A. subfam. A. Matricaria, A. } \\
\text { subfam. A. Saussurea, A. subfam. A. Senecio, A. subfam. Cichorioideae, Brassicaceae*, Caryophyl- } \\
\text { laceae ind., C. Cerastium, C. Minuartia, C. Stellaria holostea, Chenopodiaceae, Circaea, Epilobium, } \\
\text { Fabaceae*, Knautia*, Lamiaceae*, Liliaceae*, Papaveraceae, Plantago, Poaceae, Polygonaceae ind., } \\
\text { Polygonum bistorta, P. viviparum, Primulaceae*, Ranunculaceae, R. Thalictrum, Rosaceae +opercu- } \\
\text { lum, R. -operculum, R. Potentilla, R. Sanguisorba officinalis, Rumex*, R. aquatilis*, Scrophulari- } \\
\text { aceae ind., S. Pedicularis, Valeriana }\end{array}$ \\
\hline DESE/Desert & Artemisia, Chenopodiaceae, Ephedra*, Polygonaceae ind., Polygonum bistorta, P. viviparum \\
\hline
\end{tabular}

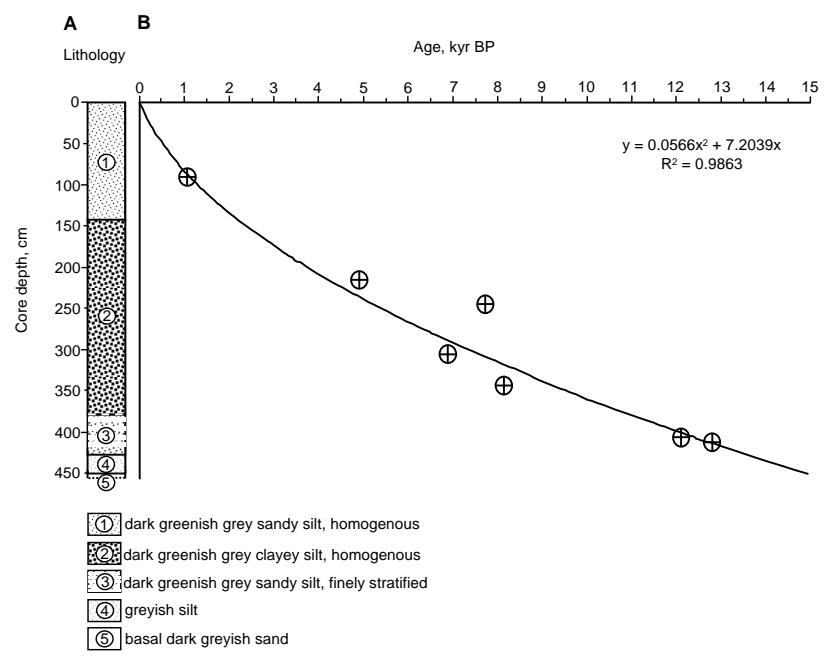

Fig. 2. Lithology (A) and age-depth model (B) of the PG1756 core from Lake Billyakh.

reconstruction as shown in Table 1. Square root transformation was applied to the pollen percentage values to diminish the influence of the most abundant pollen taxa and enhance the influence of minor taxa. Details of the method, including the equation used to calculate biome scores and discussion of the taxa attribution to the PFTs and to biomes are provided in Tarasov et al. (1998).

\subsection{Results}

\subsection{Age-depth model}

Plant material from 7 samples was radiocarbon dated at the Leibniz Laboratory for Radiometric Dating in Kiel. The age model for the PG1756 core takes into account 7 radiocarbon dates, spanning the time interval between 13 and $1 \mathrm{kyr}$ BP (Table 2). Radiocarbon years were converted to calendar years using the CalPal program available online (Danzeglocke et al., 2008). A reasonable time-depth relationship arises from a fit with a polynomial function (Fig. 2b), which then was applied for age calculation of the pollen zone boundaries and their discussion in terms of temporal changes of vegetation and climate. One date $(8356 \pm 124 \mathrm{yr}$ BP, $244 \mathrm{~cm}$ depth) seemed to be slightly older than suggested by the other dates and did not fit in with our age-depth model. The calculation was repeated without this date. However, exclusion of the date from the analysis did not influence the age model. Using the equation in Fig. $2 b$ the bottom of the analysed core can be dated to about $15 \mathrm{kyr}$ BP.

\subsection{Pollen analysis}

Complete results of the pollen analysis are provided in Appendix A. The simplified pollen percentage diagram is shown in Fig. 3 and the main results of the pollen analysis are 
Table 2. Radiocarbon dates from Lake Billyakh. Radiocarbon years are converted to calendar years (68\% range) using the CalPal program (Danzeglocke et al., 2008).

\begin{tabular}{llcll}
\hline $\begin{array}{l}\text { Laboratory } \\
\text { number }\end{array}$ & $\begin{array}{l}\text { Internal } \\
\text { core number }\end{array}$ & $\begin{array}{l}\text { Depth from } \\
\text { the core top }(\mathrm{cm})\end{array}$ & $\begin{array}{l}\text { Uncalibrated } \\
\text { age }\left({ }^{14} \mathrm{C} \text { yr BP }\right)\end{array}$ & $\begin{array}{l}\text { Calibrated } \\
\text { age }(\text { cal. yr BP })\end{array}$ \\
\hline KIA29879 & PG1756-2, 90 & 90 & $1145 \pm 40$ & $1065 \pm 62$ \\
KIA29880 & PG1756-3,30 & 214 & $4400 \pm 300$ & $4998 \pm 398$ \\
KIA34217 & PG1756-3, 60 & 244 & $7010 \pm 40$ & $7861 \pm 55$ \\
KIA34218 & PG1756-3, 120 & 304 & $6080 \pm 70$ & $6973 \pm 116$ \\
KIA34219 & PG1756-3, 160 & 344 & $7460 \pm 130$ & $8256 \pm 124$ \\
KIA34220 & PG1756-3, 220 & 404 & $10430 \pm 160$ & $12282 \pm 277$ \\
KIA29881 & PG1756-3,226 & 410 & $11105 \pm 60$ & $13002 \pm 119$ \\
\hline
\end{tabular}

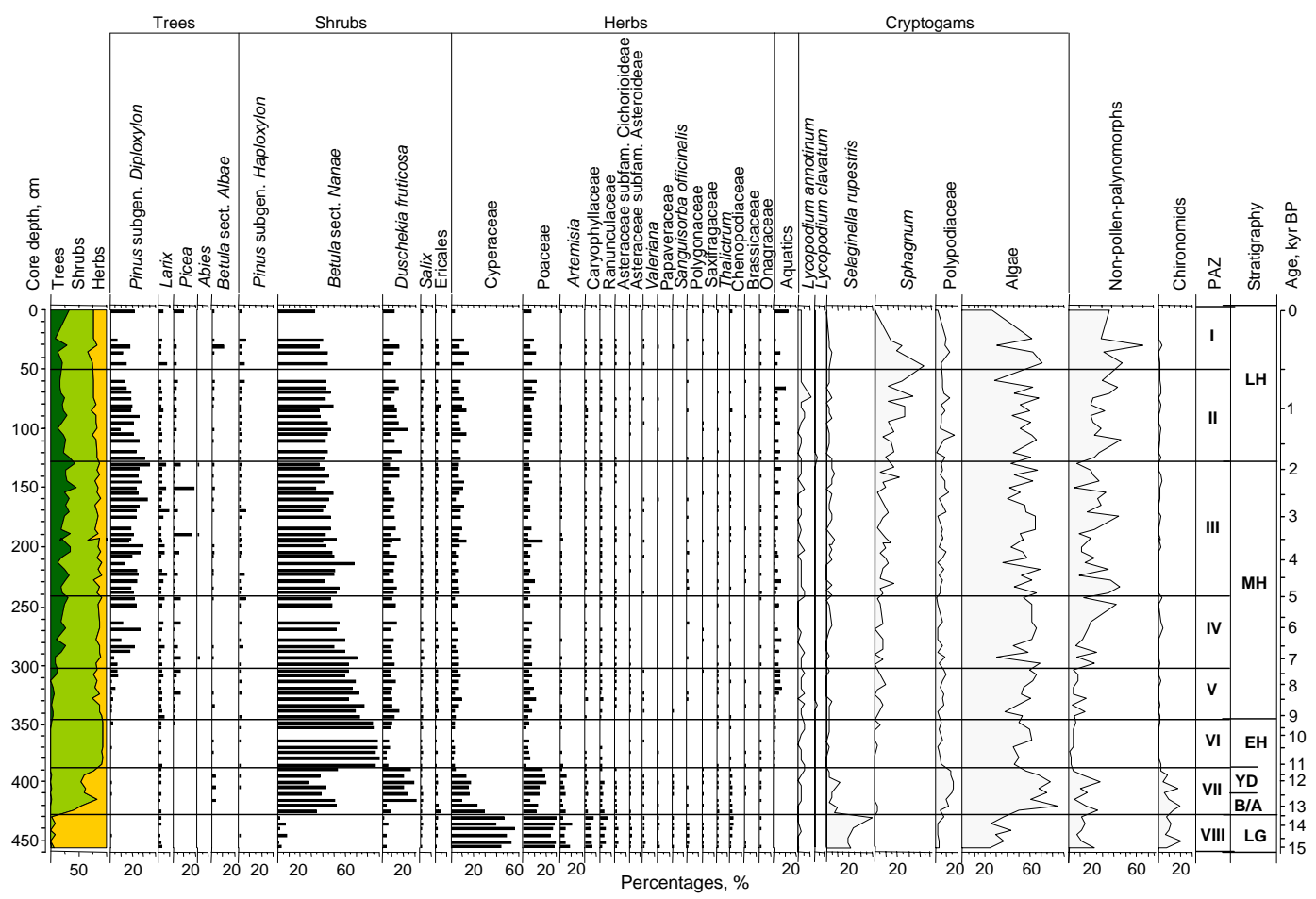

Fig. 3. Pollen percentage diagram of the PG1756 core from Lake Billyakh; LG - Late Glacial, EH- Early Holocene, B/A - Bølling-Allerød, YD - Younger Dryas, MH - Middle Holocene, LH - Late Holocene.

incorporated in the following chapter 4 for further interpretation and discussion.

\section{Interpretation and discussion}

Our results suggest distinct vegetation and environmental changes around Lake Billyakh since $15 \mathrm{kyr}$ BP related to Late Quaternary regional climate and environmental dynamics. The environmental reconstruction (Fig. 4c) is based on the qualitative interpretation of the pollen record (Figs. 3 and $4 \mathrm{a}$ ) with quantitative results of the biome reconstruction (Fig. 4b).

\subsection{Late Glacial}

The pollen assemblages prior to $13.5 \mathrm{kyr}$ BP (PAZ VIII; $455-428 \mathrm{~cm}, 15-13.5 \mathrm{kyr}$ BP) are characterised by lowest pollen concentrations through the whole record, increasing from 1900 grains/g in the lower part to 7200 grains/g in the upper part of this zone. The pollen assemblages are dominated by herbaceous taxa (89-99\%), with the highest proportion of sedge (40-57\%) and grass pollen (24-29\%) in the whole record, suggesting a wide spread of herbaceous tundra communities (Prentice et al., 1996; Tarasov et al., 1998). On the other hand, Poaceae, Artemisia, Caryophyllaceae, 

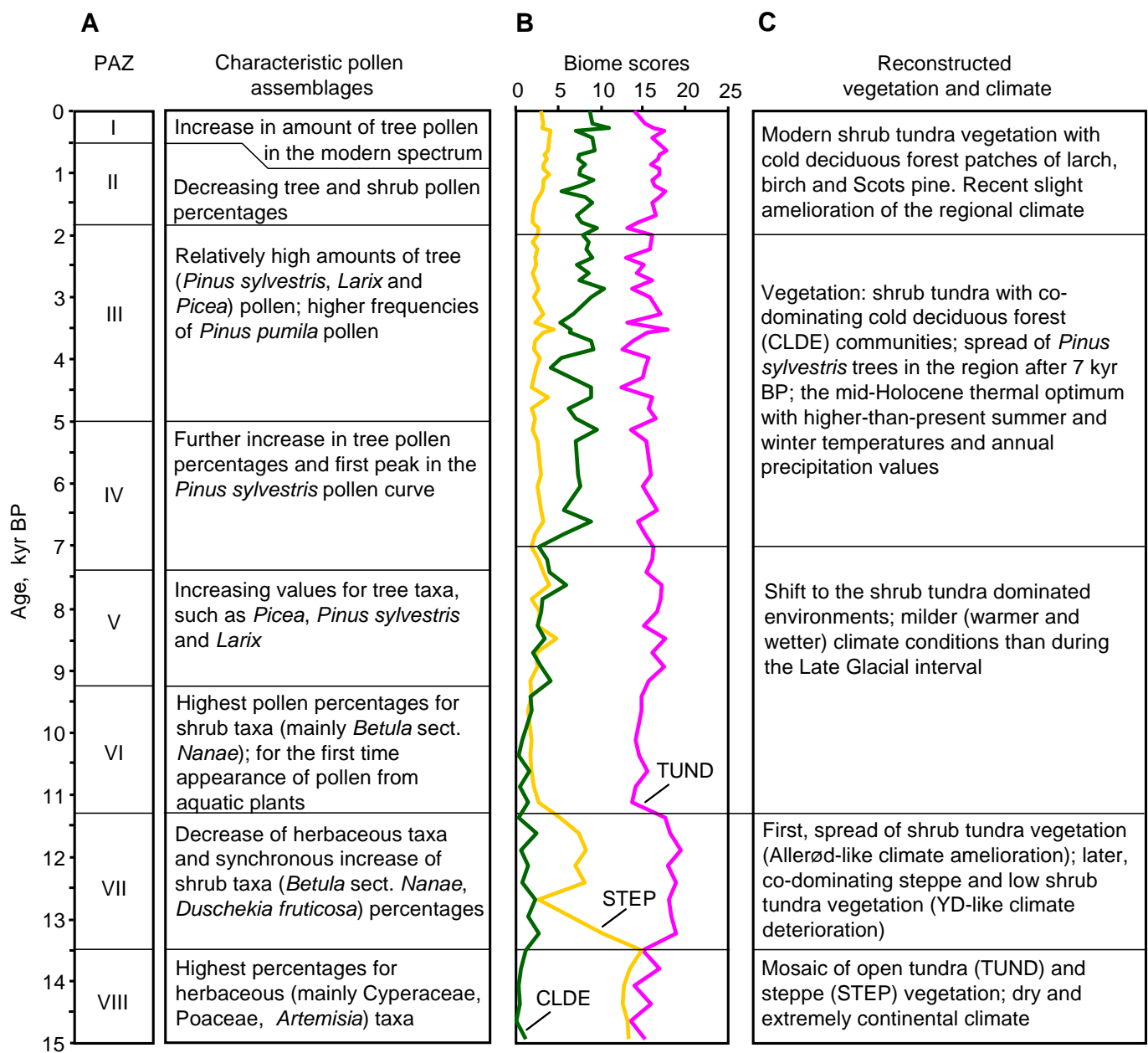

Fig. 4. Local pollen zones and pollen assemblage characteristics of the PG1756 core (A); time series of individual vegetation types (biomes) dominating in the study area since $15 \mathrm{kyr}$ BP (B); summary of the reconstructed changes in vegetation and climate around Lake Billyakh (C).

Asteraceae subfam. Cichorioideae and some other taxa attributed to the steppe biome can successfully grow in the mountain steppe and meadow communities and on the dry slopes of southern exposition (Walter, 1974). A wide spread of the dry environments is suggested by the high percentages of Selaginella rupestris spores (20-40\%). This species of spike-moss usually occurs in dry and cold rocky places with disturbed or thin soil cover. Permanent presence of arctic and alpine shrubs and dwarf shrubs represented by Betula sect. Nanae, Duschekia fruticosa and Salix (0.5-10\%) in the pollen spectra supports the interpretation of local occurrence of shrub tundra patches in the regional vegetation. The presence of Larix $(0.5-2 \%)$ in the pollen spectra moreover points to the growth of larch around the lake already during the early Late Glacial about $15 \mathrm{kyr}$ ago. This conclusion is based on the consideration that larch pollen is usually strongly underrepresented in the pollen diagrams and poorly transported far from the pollen-producing tree (Tarasov et al., 1998; Pisaric et al., 2001).
Results of the biome reconstruction demonstrate almost equally high scores for the tundra and steppe biomes and low scores for the cold deciduous forest biome, suggesting the reconstruction of generally open tundra-steppe vegetation between 15 and $13.5 \mathrm{kyr}$ BP. Grichuk (1984) pointed out that such plant communities were typical for the periglacial steppe or "tundra-steppe" vegetation of the LGM, which was widely distributed in northern Eurasia. Predominance of herbaceous steppe-like vegetation prior to $13.7 \mathrm{kyr} \mathrm{BP}$ is suggested by the pollen record from Levinson-Lessing Lake $\left(74^{\circ} 28^{\prime} \mathrm{N} ; 98^{\circ} 38^{\prime} \mathrm{E}\right)$ in the northeastern Taymyr Peninsula (Andreev and Tarasov, 2007; Table 3). At that time dwarf shrub tundra had limited coverage and survived only in the locally wet habitats. Similar vegetation cover is reconstructed from the Lake Dolgoe $\left(71^{\circ} 52^{\prime} \mathrm{N}, 127^{\circ} 04^{\prime} \mathrm{E}\right)$ pollen record in the lower Lena River before $14.5 \mathrm{kyr}$ BP (Pisaric et al., 2001). According to the Biome 4 vegetation model, dominance of herbaceous vegetation in the Arctic can be explained by the extremely continental climate with low 
Table 3. Summary of major vegetation changes and climate trends reported for the sites mentioned in the discussion.

\begin{tabular}{|c|c|c|c|c|}
\hline Site & Period, age & $\begin{array}{l}\text { Pollen assemblages and vegetation } \\
\text { characteristics }\end{array}$ & Climate reconstructions & References \\
\hline \multirow{6}{*}{$\begin{array}{l}\text { 1. Levinson-Lessing Lake; } \\
74^{\circ} 28^{\prime} \mathrm{N}, 98^{\circ} 38^{\prime} \mathrm{E} \\
47 \mathrm{~m} \text { a.s.1. }\end{array}$} & until 13.7 kyr BP & Scarce steppe-like vegetation & Severe continental climate & $\begin{array}{l}\text { Andreev and Tarasov, } \\
2007\end{array}$ \\
\hline & after 13.7 kyr BP & $\begin{array}{l}\text { Dramatic increases in shrub birch and } \\
\text { willow pollen and in total pollen con- } \\
\text { centration }\end{array}$ & $\begin{array}{l}\text { Climatic amelioration, sum- } \\
\text { mer temperature } 2-4^{\circ} \mathrm{C} \text { higher } \\
\text { than present }\end{array}$ & \\
\hline & between 13 and $12 \mathrm{kyr} \mathrm{BP}$ & $\begin{array}{l}\text { Increase in sedge, grass, and herb } \\
\text { pollen }\end{array}$ & & \\
\hline & About $11.5-11.2 \mathrm{kyr} \mathrm{BP}$ & $\begin{array}{l}\text { Shift in vegetation from herb- } \\
\text { dominated to shrubby birch-willow } \\
\text { tundra }\end{array}$ & $\begin{array}{l}\text { Summer temperature } 3-4^{\circ} \mathrm{C} \\
\text { higher than today, precipita- } \\
\text { tion about } 100 \mathrm{~mm} \text { higher }\end{array}$ & \\
\hline & After $6.3 \mathrm{kyr}$ BP & & $\begin{array}{l}\text { Summer temperature became } \\
\text { similar to present }\end{array}$ & \\
\hline & After 3.2 kyr BP & $\begin{array}{l}\text { Vegetation became similar to the mod- } \\
\text { ern herb tundra }\end{array}$ & & \\
\hline \multirow{4}{*}{$\begin{array}{l}\text { 2. Lake Dolgoe; } \\
71^{\circ} 52^{\prime} \mathrm{N}, 127^{\circ} 04^{\prime} \mathrm{E} \text {; } \\
40 \mathrm{~m} \text { a.s. } 1 .\end{array}$} & $12.3^{14} \mathrm{C}$ kyr BP & Herb and shrub dominated tundra & & Pisaric et al., 2001 \\
\hline & $\begin{array}{l}\text { between } 11 \text { and } 10{ }^{14} \mathrm{C} \text { kyr BP yr } \\
\text { BP }\end{array}$ & $\begin{array}{l}\text { Decrease in shrub birch and increases } \\
\text { in grass and herbaceous plants }\end{array}$ & cooling & \\
\hline & Between 8.5 and $3.5^{14} \mathrm{C}$ kyr BP & Spread of forests in the region & & \\
\hline & After $3.5{ }^{14} \mathrm{C}$ kyr BP & Establishment of modern vegetation & & \\
\hline \multirow{4}{*}{$\begin{array}{l}\text { 3. Lake Chabada; } \\
61^{\circ} 59^{\prime} \mathrm{N}, 129^{\circ} 22^{\prime} \mathrm{E} \\
290 \mathrm{~m} \text { a.s.1. }\end{array}$} & ca. $13.4 \mathrm{kyr} \mathrm{BP}$ & Quick afforestation & warming & Tarasov et al., 2007 \\
\hline & between 13 and $12 \mathrm{kyr}$ BP & Low woody cover & cooling & \\
\hline & After 12 kyr BP & $\begin{array}{l}\text { Expansion of birch and larch } \\
\text { dominated forests }\end{array}$ & & \\
\hline & After $7 \mathrm{kyr}$ BP & Spread of Pinus sylvestris & & \\
\hline \multirow{6}{*}{$\begin{array}{l}\text { 4. Smorodinovoye Lake; } \\
64^{\circ} 46^{\prime} \mathrm{N}, 141^{\circ} 06^{\prime} \mathrm{E} \\
798 \mathrm{~m} \text { a.s.l. }\end{array}$} & Until $10.8{ }^{14} \mathrm{C}$ kyr BP & Glacial tundra & & Anderson et al., 2002 \\
\hline & Ca. $10.8-10.2{ }^{14} \mathrm{C}$ kyr BP & transitional shrub tundra & $\begin{array}{l}\text { Mean July temperatures be- } \\
\text { tween } 10 \text { and } 12^{\circ} \mathrm{C}\end{array}$ & \\
\hline & Ca. $10.2-9.9^{14} \mathrm{C}$ kyr BP & Herb dominated tundra & Summer temperatures $<10^{\circ} \mathrm{C}$ & \\
\hline & Ca. $9.6{ }^{14} \mathrm{C}$ kyr BP & Arrival of larch in the lake area & & \\
\hline & Ca. $6.1{ }^{14} \mathrm{C}$ kyr BP until today & Development of modern forests & & \\
\hline & Between 6 and $4{ }^{14} \mathrm{C}$ kyr BP & & $\begin{array}{l}\text { Occurence of maximum post- } \\
\text { glacial summer temperatures }\end{array}$ & \\
\hline \multirow{4}{*}{$\begin{array}{l}\text { 5. Bol'shoy Lyakhovsky } \\
\text { Island; } 73^{\circ} 20^{\prime} \mathrm{N}, \\
141^{\circ} 30^{\prime} \mathrm{E} ;<35 \mathrm{~m} \text { a.s.1. }\end{array}$} & $11.6-11.3^{14} \mathrm{C}$ kyr BP & grass-sedge dominated vegetation & $\begin{array}{l}\text { Summer temperatures were } \\
4^{\circ} \mathrm{C} \text { higher than today }\end{array}$ & Andreev et al., 2009 \\
\hline & ca. $11-10^{14} \mathrm{C}$ kyr BP & $\begin{array}{l}\text { Grass-sedge, few shrubs, low } \\
\text { pollen concentration }\end{array}$ & Climate deterioration & \\
\hline & $\begin{array}{l}\text { between } 9 \text { and } 7.5^{14} \mathrm{C} \text { kyr BP kyr } \\
\text { BP }\end{array}$ & $\begin{array}{l}\text { Predominance of shrub alder and dwarf } \\
\text { birch tundra }\end{array}$ & & \\
\hline & after $7.6^{14} \mathrm{C}$ kyr BP & $\begin{array}{l}\text { Establishment of modern tundra envi- } \\
\text { ronments }\end{array}$ & Slightly warmer than today & \\
\hline
\end{tabular}

precipitation and severe winter conditions (Kaplan, 2001). The model also suggests that in such environments, snow thickness of less than $15 \mathrm{~cm}$ during the winter would result in disappearance of perennial shrubs from the tundra vegetation.

During the second half of the Late Glacial (13.4-11.3 kyr) both pollen assemblages composition and the dominant biome scores (Fig. 4b) suggest a distinct two-step change in the vegetation and environment of the study area, which roughly corresponds to the Bølling-Allerød Interstadial and the Younger Dryas Stadial. PAZ VII (427-387 cm, 13.4-
$11.3 \mathrm{kyr} \mathrm{BP})$ is characterised by a noticeable increase in pollen concentrations from 13500 to 72700 grains/g. Recorded increases in Betula sect. Nanae (26-52\%) and Duschekia fruticosa (up to $29 \%$ at $114 \mathrm{~cm}$ ) pollen percentages indicate that birch- and alder-dominated shrub tundra communities started to play a greater role in the study area between 13.4 and $12.5 \mathrm{kyr}$ BP. A great reduction of the drought tolerant vegetation communities is also suggested by a significantly lower content of the rock spike moss spores $(3-10 \%)$. 


\subsubsection{Bølling-Allerød Interstadial}

Biome reconstruction shows a pronounced decrease in steppe biome scores and highest scores for the tundra biome, suggesting replacement of the former tundra-steppe vegetation by the herb and shrub tundra communities. Such change in the vegetation would imply a quick shift to wetter environments caused by increased precipitation and/or melting of permafrost due to summer warming and decreasing winter temperature during the Bølling-Allerød Interstadial (Grichuk, 1984). A dramatic increase in shrub birch and willow pollen associated with a significant decrease in herbaceous pollen taxa occurs in the pollen record from LevinsonLessing Lake after 13.7 kyr BP (Andreev and Tarasov, 2007), and establishment of shrub birch tundra between 14.5 and 13 kyr BP is reconstructed from the Dolgoe Lake pollen record (Pisaric et al., 2001) in response to the climate amelioration during the Allerød interval. Reviewing climate changes in East Europe and Siberia at the Late Glacial-Holocene transition, Velichko et al. (2002) provided a quantitative reconstruction of the Allerød climate anomalies at two sites from central Yakutia. The pollen-based reconstructions suggest that mean January temperatures were $1.5-3^{\circ} \mathrm{C}$, mean July temperature were $1^{\circ} \mathrm{C}$ and annual precipitation was 25$60 \mathrm{~mm}$ below the present-day values.

\subsubsection{Younger Dryas Stadial}

After 12.5 kyr BP both the pollen spectra composition and the steppe biome score demonstrate a short-term strengthening of the herbaceous vegetation communities compared to the shrub tundra vegetation, suggesting a decrease in available moisture and possibly a decrease in winter temperatures. This episode of climate deterioration deduced from the Lake Billyakh record is dated to $12.4-11.3 \mathrm{kyr} \mathrm{BP}$, thus falling well within the age limits of the Younger Dryas Stadial known for its generally colder and dryer climate, particularly in the North Atlantic sector. Velichko et al. (2002) also reconstructed severe climate deterioration in Siberia, particularly during the winter time. Consistent with earlier climate reconstructions in this region, our record suggests that the Younger Dryas climate around Lake Billyakh was not as cold and dry as during the 15-13.5 kyr BP interval. The presence of Larix in the pollen record and likely in the vegetation cover, as well as relatively high contents of birch and alder shrub pollen and high tundra biome scores, reflects moisture availability. Summer temperatures were high enough to sustain the survival of boreal trees and shrubs.

\subsection{Early Holocene}

After $11.3 \mathrm{kyr}$ BP the pollen record suggests a shift to shrub tundra dominated environments and milder climate conditions than during the Late Glacial. PAZ VI (386$347 \mathrm{~cm}, 11.2-9.3 \mathrm{kyr} \mathrm{BP})$ includes the highest pollen concentration (up to 211900 grains/g) and PAZ V (346-303 cm,
9.2-7.4 kyr BP) is characterised by a relatively high pollen concentration (up to 97500 grains/g). Shrub taxa absolutely dominate in the pollen spectra (up to 95\%), and steppe biome scores reach minimum values through the whole record. These changes inferred from the PG1756 record indicate the onset of the Holocene Interglacial, in line with other records from the region (Fradkina et al., 2005; Pisaric et al., 2001; Andreev and Tarasov, 2007). However, the Lake Chabada $\left(61^{\circ} 59^{\prime} \mathrm{N} ; 129^{\circ} 22^{\prime} \mathrm{E}, 290 \mathrm{~m}\right.$ a.s.l.) pollen record from central Yakutia demonstrates a locally quick spread of boreal forest soon after $12 \mathrm{kyr}$ BP (Tarasov et al., 2007). Location of the lake on the ancient erosion-accumulative plain of the Lena River, which provides locally favourable conditions for arboreal vegetation, may explain this difference in low scores of the forest biome in the Lake Billyakh record during the Early Holocene. The already mentioned under-representation of larch - the dominant taxon in the regional cold deciduous forest - in the pollen records from larger lakes is another possible explanation. The fact that more or less constant amounts of Larix pollen (0.5-4\%) occur throughout the whole record provides support for such interpretation.

The Early Holocene (11-8 kyr BP) thermal maximum in the Arctic is explained by a combined effect of higher-thanpresent Northern Hemisphere summer insolation and much lower-than-present sea level (Lozhkin and Anderson, 2006). The substantial warming at the Late Glacial-Holocene transition is recorded in various arctic regions of the Northern Hemisphere (e.g. MacDonald et al., 2000a; Andreev et al., 2004; Kaufman et al., 2004; Kaplan and Wolfe, 2006), including Smorodinovoye Lake ( $64^{\circ} 46^{\prime} \mathrm{N} ; 141^{\circ} 06^{\prime} \mathrm{E}$; $798 \mathrm{~m}$ a.s.l.) east of the Verkhoyansk Mountains (Anderson et al., 2002) as well as at sites from central Yakutia west of the Verkhoyansk Range (Velichko et al., 1997). However, the latter study suggests that both January and July temperatures and annual precipitation were lower than today by $1^{\circ} \mathrm{C}, 0.5^{\circ} \mathrm{C}$ and $25 \mathrm{~mm} / \mathrm{yr}$, respectively. Summer temperatures at least $4^{\circ} \mathrm{C}$ warmer than present are reconstructed at the Bol'shoy Lyakhovsky Island (Andreev et al., 2009) in the East Siberian Sea, suggesting that warming was more pronounced in northern Yakutia than in central and southern Yakutia. This corroborates the inference of an initial spread of boreal forest across northern Asia after $11.5 \mathrm{kyr} \mathrm{BP}$, the advance towards the current Arctic coastline between 10 and $8 \mathrm{kyr} \mathrm{BP}$, and its retreat to its present position after $4.5 \mathrm{kyr}$ BP (MacDonald et al., 2000a).

\subsection{Middle Holocene}

The pollen spectra of PAZ IV (302-242 cm, 7.3-5 kyr BP) and PAZ III (241-129 cm, 5-1.8 kyr BP) are characterised by relatively high (80200-104 100 grains/g) and moderately high (40200-87000 grains/g) pollen concentrations and closely resemble modern surface pollen spectra from the study area, suggesting that vegetation around Lake Billyakh became similar to modern vegetation already in the Middle 
Holocene after $7 \mathrm{kyr}$ BP. Biome reconstruction demonstrates an increase in the forest biome scores, suggesting that cold deciduous and taiga forests strengthened their positions in the region. Our pollen record shows a fourfold increase in Pinus subgen. Diploxylon percentages (12-34\%), reflecting the spread of Pinus sylvestris in the region after $7 \mathrm{kyr}$ BP. This feature is in good agreement with other study results carried out in northeastern Siberia (Andreev et al., 1997, 2002; MacDonald et al., 2000a; Pisaric et al., 2001; Andreev and Tarasov, 2007). MacDonald et al. (2000b) pointed out that lower-than-present winter insolation and associated cold and dry winter conditions might have caused desiccation and root damage of Pinus sylvestris, restricting its earlier spread in northern Eurasia. In turn, warmer-than-present midHolocene summers in conjunction with an orbitally-induced increase in winter insolation and sea-level rise caused further degradation of permafrost and promoted the spread of Scots pine and in a broader regional context, spruce and Siberian pine taiga forest (Andreev and Tarasov, 2007). The appearance of wind transported Abies in PAZ IV and III of our record is consistent with the mid-Holocene amelioration of the regional climate, since fir is one of the most sensitive Siberian trees to winter temperature and moisture availability (Tarasov et al., 2007). The Smorodinovoye Lake pollen record (Anderson et al., 2002) indicates that mid-Holocene climatic changes in the upper Indigirka basin resemble those in the Lake Billyakh area. Both records suggest that maximum postglacial warming occurred after $7 \mathrm{kyr}$ BP, thus a few thousand years later than in the northern and northeastern records of the arctic region. Actually, this timing of maximum warming is more consistent with postglacial climate development in central and northern Europe (e.g. Davis et al., 2003), suggesting strong climate teleconnections to Europe via the westerly wind system.

\subsection{Late Holocene}

The Late Holocene pollen spectra from Lake Billyakh are characterised by a decrease in pollen concentrations to 22300 grains/g in PAZ II $(128-50 \mathrm{~cm}, 1.8-0.5 \mathrm{kyr} \mathrm{BP})$ and to 15300 grains/g in PAZ I (49-0 cm, 0.5-0 kyr BP). The spectra show a progressive increase in the amount of herbaceous (11-29\%) pollen during the last $2 \mathrm{kyr}$. This trend is accompanied by a distinct minimum in the Pinus subgen. Diploxylon (11\%) pollen percentages about two to three hundred years ago. The later change might be associated with intensified human activities (e.g. the migration and spread of semi-nomadic Yakuts into the Middle Lena region since early medieval time) and/or with climate deterioration during the "Neoglacial" and particularly during the Little Ice Age. Popp et al. (2006) inferred a cold signal from stableisotope composition of ground ice younger than $1 \mathrm{kyr}$ BP in the Verkhoyansk Mountains Foreland. However, the question of human-environmental interactions in the region during the past millennia needs further investigation.

\section{Conclusions}

In the recent study we present first detailed and well dated pollen record from the Verkhoyansk Mountains, the coldest region of Eurasia and Northern Hemisphere. The pollen record is then interpreted in terms of Late Glacial and Holocene vegetation and climate dynamics. Our reconstruction demonstrates substantial changes in the regional vegetation during the past $15 \mathrm{kyr}$. Major changes in the pollen assemblages and vegetation can be associated with well recognised large-scale palaeoclimatic events, the Allerød warming and Younger Dryas cooling, the onset of the Holocene and Middle Holocene thermal optimum.

The most severe cold and dry conditions are documented in the oldest part of our record, between 15-13.5 kyr BP when the landscape was mainly covered by mosaic herbaceous (tundra and steppe) and rock spike moss vegetation. During 13.4-12.5 kyr BP the region experienced climate amelioration and spread of shrub tundra communities associated with the Bølling-Allerød Interstadial, followed (12.4$11.3 \mathrm{kyr} \mathrm{BP}$ ) by a return to the relatively cold-dry conditions associated with the Younger Dryas Stadial. The Younger Dryas climate, however, was less severe than conditions before $13.5 \mathrm{kyr} \mathrm{BP}$, as suggested by higher percentages of tree and shrub pollen. Climate amelioration associated with the onset of the Holocene is dated to $11.2 \mathrm{kyr}$ BP. Subsequently, steppe elements played a minor role in the vegetation cover, shrub tundra communities became dominant and boreal woods started to play a greater role in the vegetation cover. Both species richness and spatial extent of the forests reached their maximum between 7 and $2 \mathrm{kyr}$ BP.

Another important aspect of the Lake Billyakh pollen record is that it demonstrates the uninterrupted growth of larch in the study area during the past $15 \mathrm{kyr}$, as indicated by the persistence of Larix pollen in the whole record. This conclusion confirms an earlier hypothesis of Grichuk (1984), who postulated the existence of many scattered refugia where boreal shrubs and trees could survive periods of harsh glacial climate and quickly spread with the onset of warmer conditions. We suggest that small populations of larch in the Verkhoyansk foreland and in the nearby Lena River valley had locally sufficient water supplies and high enough summer temperatures for growth and reproduction during the Late Glacial. To verify the presence of larch around Lake Billyakh during the LGM we intend to perform a detailed pollen analysis of the $9 \mathrm{~m}$ long PG1755 sediment core, which covers the time interval since $50 \mathrm{kyr}$ BP until today.

\section{Appendix A}

Results of the pollen analysis of the PG1756 core from Lake Billyakh $\left(65.27^{\circ} \mathrm{N}, 126.75^{\circ} \mathrm{E} ; 340 \mathrm{~m}\right.$ a.s.1.). Absolute count values are provided for each identified taxon at each analysed level. Sample ages (cal. yr BP) are calculated using 
age-depth model discussed in the text. All raised palynological data are available in the PANGAEA data information system (see doi:10.1594/PANGAEA.708170).

Acknowledgements. Field work, including coring and transportation of the core material, was funded by the Alfred Wegener Institute for Polar and Marine Research (Research Unit Potsdam). We would like to acknowledge the help of D. Gruznykh, H. Lüpfert, G. Müller, L. Pestryakova, and D. Subetto and financial support from the German Research Foundation (DFG) via the projects RI 809/17 "Late Quaternary environmental history of interstadial and interglacial periods in the Arctic reconstructed from bioindicators in permafrost sequences in NE Siberia" and TA 540/1 "Comparison of climate and carbon cycle dynamics during Late Quaternary interglacials using a spectrum of climate system models, ice-core and terrestrial archives". We thank A. Beck for checking English grammar and spelling; and J. Guiot, O. Peyron and the anonymous reviewer for comments and suggestions improving the manuscript.

Edited by: J. Guiot

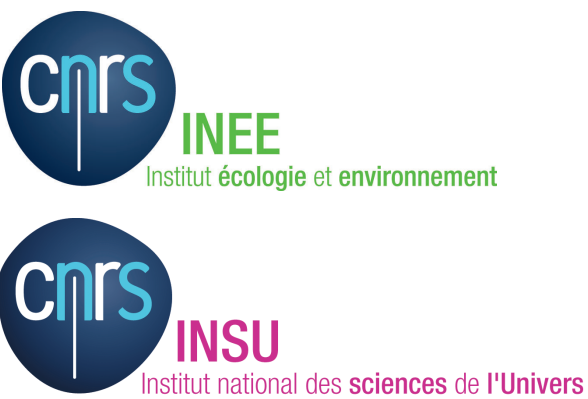

Publication of this paper was granted by EDD (Environnement, Développement Durable) and INSU (Institut des Sciences de l'Univers) at CNRS.

\section{References}

ACIA: Impacts of a warming Arctic: Arctic Climate Impact Assessment, Cambridge University Press, Cambridge, 2004.

Alpat'ev, A. M., Arkhangel'skii, A. M., Podoplelov, N. Y., and Stepanov, A. Y.: Fizicheskaya geografiya SSSR (Aziatskaya chast'), Vysshaya Shkola, Moscow, 1976, (in Russian).

Anderson, P. M., Lozhkin, A. V., and Brubaker, L. B.: Implications of a 24,000-Yr palynological record for a Younger Dryas cooling and for Boreal forest development in northeastern Siberia, Quaternary Res., 57, 325-333, 2002.

Andreev, A. A. and Klimanov, V. A.: Vegetation and climate history of Central Yakutia during the Holocene and Late Pleistocene, in: Formirovanie rel'efa, korelyatnykh otlozheny i rossypei SeveroVostoka SSSR, edited by: Ivanov, B. F. and Palymsky, B. F., SVKNII, Magadan, 28-51, 1989, (in Russian).

Andreev, A. A., Klimanov, V. A., and Sulerzhitsky, L. D.: Younger Dryas pollen record from Central and Southern Yakutia, Quatern. Int., 41/42, 111-117, 1997.

Andreev, A. A., Klimanov, V. A., and Sulerzhitsky, L. D.: Vegetation and climate history of Central Yakutia during the Holocene and late Pleistocene, Botanicheskiy Zhurnal, 87, 86-98, 2002, (in Russian).
Andreev, A. A., Tarasov, P. E., Klimanov, V. A., Melles, M., Lisitsyna, O. M., and Hubberten, H.-W.: Vegetation and climate changes around the Lama Lake, Taymyr Peninsula, Russia during the Late Pleistocene and Holocene, Quatern. Int., 122, 69-84, 2004.

Andreev, A. A. and Tarasov, P. E.: Pollen records, postglacial: Northern Asia, in: Encyclopedia of Quaternary Science, vol. 4., edited by: Elias, S. A., Elsevier, Amsterdam, Netherlands, 27212729, 2007.

Andreev, A. A., Grosse, G., Schirrmeister, L., Kuznetsova, T. V., Kuzmina, S. A., Bobrov, A. A., Tarasov, P. E., Novenko, E. Yu., Meyer, H., Derevyagin, A. Yu., Kienast, F., Bryantseva, A., and Kunitsky, V. V.: Weichselian and Holocene palaeoenvironmental history of the Bol'shoy Lyakhovsky Island, New Siberian Archipelago, Arctic Siberia, Boreas, 38, 72-110, 2009.

Beug, H.-J.: Leitfaden der Pollenbestimmung für Mitteleuropa und angrenzende Gebiete, Verlag Dr. Friedrich Pfeil, München, 542 pp., 2004.

Bobrov, A. E., Kuprianova, L. A., Litvintseva, M. V., and Tarasevich, V. F.: Spores and pollen of gymnosperms from the flora of the European part of the USSR, Nauka, Leningrad, 208 pp., 1983, (in Russian).

Cwynar, L. E., Burden, E., and McAndrews, J. H.: An inexpensive sieving method for concentrating pollen and spores from finegrained sediments, Can. J. Earth. Sci., 16, 1115-1120, 1979.

Danzeglocke, U., Jöris, O., and Weninger, B.: CalPal-2007, last access: 12 July 2008. http://www.calpal-online.de, 2008.

Davis, B. A. S., Brewer, S., Stevenson, A. C., Guiot, J., and Data Contributors: The temperature of Europe during the Holocene reconstructed from pollen data, Quat. Sci. Rev., 22, 1701-1716, 2003.

Diekmann, B., Andreev, A., Müller, G., Lüpfert, H., Pestryakova, L., Subetto, D.: Expedition “Verkhoyansk 2005”, Limnogeological studies at Lake Billyakh, Verkhoyansk Mountains, Yakutia, in: Expeditions in Siberia in 2005, edited by: Schirrmeister, L., Reports on Polar and Marine Research, 550, 247-258, AWI Bremerhaven, 2007.

Fægri, K., Kaland, P. E., and Krzywinski, K.: Textbook of Pollen Analysis, 4th edition, John Wiley \& Sons, Chichester, 1989.

Fradkina, A. F., Alekseev, M. N., Andreev, A. A., and Klimanov, V. A.: East Siberia, in: Cenozoic climatic and environmental changes in Russia, edited by: Velichko, A. A., Nechaev, V. P., Wright Jr., H. E., Blyakharchuk, T. A., and Borisova, O. K., The Geological Society of America, Boulder, Colorado, USA, 89103, 2005.

French, H. and Williams, P.: The periglacial environment, $3^{r d}$ ed., Wiley, John \& Sons, Incorporated, 448 pp., 2007.

Gavrilova, M. K.: Climate and permafrost, Permafrost Periglac., 4, 99-111, 1993.

Grichuk, V. P.: Late Pleistocene vegetation history, in: Late Quaternary environments of the Soviet Union, edited by: Velichko, A. A., University of Minnesota Press, Minneapolis, USA, 155-178, 1984.

Grimm, E. C.: TILIA 2.0 Version b.4 (Computer Software), Illinois State Museum, Research and Collections Center, Springfield, 1993.

Grimm, E. C.: TGView, Illinois State Museum, Research and Collections Center, Springfield, 2004.

International Council for Science (ICSU): A Framework for the In- 
ternational Polar Year 2007-2008, produced by the ICSU IPY 2007-2008 Planning Group, 2004.

Kaplan, J. O.: Geophysical Applications of Vegetation Modelling, Ph.D. thesis, Lund University, Sweden, 2001.

Kaplan, M. R. and Wolfe, P. W.: Spatial and temporal variability of Holocene temperature in the North Atlantic region, Quaternary Res., 65, 223-231, 2006.

Kaufman, D. S., Ager, T. A., Anderson, N. J., Anderson, P. M., Andrews, J. T., Bartlein, P. J., Brubaker, L. B., Coats, L. L., Cwynar, L. C., Duvall, M. L., Dyke, A. S., Edwards, M. E., Eisner, W. R., Gajewski, K., Geirsdóttir, A., Hu, F. S., Jennings, A. E., Kaplan, M. R., Kerwin, M. W., Lozhkin, A. V., MacDonald, G. M., Miller, G. H., Mock, C. J., Oswald, W. W., Otto-Bliesner, B. L., Porinchu, D. F., Rühland, K. M., Smol, J. P., Steig, E. J., and Wolfe, B. B.: Holocene thermal maximum in the western Arctic $\left(0-180^{\circ} \mathrm{W}\right)$, Quat. Sci. Rev., 23, 529-560, 2004.

Khotinsky, N. A.: The Holocene in northern Eurasia, Nauka Moscow, 1-198, 1977, (in Russian).

Kupriyanova, L. A. and Alyoshina L. A.: Pollen and spores of plants from the flora of European part of USSR. Vol. I., Acad. Sci. USSR, Komarov. Bot. Inst., Leningrad, 170 pp., 1972, (in Russian).

Kupriyanova, L. A. and Alyoshina L. A.: Pollen and spores of plants from the flora of European part of USSR, Acad. Sci. USSR, Komarov. Bot. Inst., Leningrad, 184 pp., 1978, (in Russian).

Lozhkin, A. V. and Anderson, P. A.: A Reconstruction of the Climate and Vegetation of Northeastern Siberia Based on Lake Sediments, Paleontological Journal, 40, 5, 622-628, 2006.

MacDonald, G. M., Velichko, A. A., Kremenetski, C. V., Borisova, O. K., Goleva, A. A., Andreev, A. A., Cwynar, L. C., Riding, R. T., Forman, S. L., Edwards, T. W. D., Aravena, R., Hammarlund, D., Szeicz, J. M., and Gattaulin, V. N.: Holocene treeline history and climate change across Northern Eurasia, Quaternary Res., 53, 302-311, 2000a.

MacDonald, G. M., Gervais, B. R., Snyder, J. A., Tarasov, G. A., and Borisova, O. K.: Radiocarbon dated Pinus sylvestris L. wood from beyond treeline on the Kola Peninsula, Russia, The Holocene, 10, 143-147, 2000b.

Peterson, G. M.: Vegetational and climate history of the western former Soviet Union, in: Global climates since the Last Glacial Maximum, edited by: Wright, H. E., Kutzbach, J. E., Webb III, T., Ruddiman, W. F., Street-Perrott, F. A., and Bartlein, P. J., University of Minnesota Press., Minneapolis, 169-193, 1993.

Pisaric, M. F. J., MacDonald, G. M., Velichko, A. A., and Cwynar, L. C.: The Lateglacial and Postglacial vegetation history of the northwestern limits of Beringia, based on pollen, stomate and tree stump evidence, Quaternary Sci. Rev., 20, 235-245, 2001.

Popp, S., Diekmann, B., Meyer, H., Siegert, C., Syromyatnikov, I., and Hubberten, H.-W.: Palaeoclimate signals as inferred from stable-isotope composition of ground ice in the Verkhoyansk Foreland, Central Yakutia, Permafrost Periglac., 17, 119-132, 2006.

Popp, S., Belolyubsky, I., Lehmkuhl, F., Prokopiev, A., Siegert, C., Spektor, V., Stauch, G. and Diekmann, B.: Sediment provenance of Late Quaternary morainic, fluvial and loess-like deposits in the southwestern Verkhoyansk Mountains (eastern Siberia) and implications for regional palaeoenvironmental reconstructions, Geol. J., 42, 477-497, 2007.
Prentice, C. I., Guiot, J., Huntley, B., Jolly, D., and Cheddadi, R.: Reconstructing biomes from palaeoecological data: a general method and its application to European pollen data at 0 and $6 \mathrm{ka}$, Clim. Dynam., 12, 185-194, 1996.

Prentice, I. C. and Jolly, D., and BIOME 6000 participants: MidHolocene and glacial maximum vegetation geography of the northern continents and Africa, J. Biogeogr., 27, 507-519, 2000.

Reille, M.: Pollen et spores d'Europe et d'Afrique du nord, Laboratoire de Botanique historique et Palynologie, Marseille, 543 pp., 1992.

Reille, M.: Pollen et spores d'Europe et d'Afrique du nord, supplement 1, Laboratoire de Botanique historique et Palynologie, Marseille, 331 pp., 1995.

Reille, M.: Pollen et spores d'Europe et d'Afrique du nord, supplement 2, Laboratoire de Botanique historique et Palynologie, Marseille, 534 pp., 1998.

Rivas-Martínez, S.: Climate diagrams, worldwide bioclimatic classification system. Phytosociological Research Center, Spain. Online database, 1996-2004. http://www.globalbioclimatics.org/ plot/ru-ust--.htm, access 7 July 2008.

Shahgedanova, M., Perov, V., and Mudrov, Y.: The Mountains of Northern Russia, in: Physical Geography in northern Eurasia, Shahgedanova, M., Oxford University Press, Oxford, 284-313, 2002.

Stauch, G.: Jungquartäre Landschaftsentwicklung im Werchojansker Gebirge, PhD thesis, RWTH Aachen, 197 pp., 2006.

Stauch, G., Lehmkuhl, F., and Frechen, M.: Luminescence chronology from the Verkhoyansk Mountains (North-Eastern Siberia), Quaternary Geochronology, 2, 255-259, 2007.

Stockmarr, J.: Tablets with spores used in absolute pollen analysis, Pollen et Spores, 13, 614-621, 1971.

Tarasov, P. E., Webb III, T., Andreev, A. A., Afanas'eva, N. B., Berezina, N. A., Bezusko, L. G., Blyakharchuk, T. A., Bolikhovskaya, N. S., Cheddadi, R., Chernavskaya, M. M., Chernova, G. M., Dorofeyuk, N. I., Dirksen, V. G., Elina, G. A., Filimonova, L. V., Glebov, F. Z., Guiot, J., Gunova, V. S., Harrison, S. P., Jolly, D., Khomutova, V. I., Kvavadze, E. V., Osivopa, I. M., Panova, N. K., Prentice, I. C., Saarse, L., Sevastyanov, D. V., Volkova, V. S., and Zernitskaya, V. P.: Present day and midHolocene biomes reconstructed from pollen and plant macrofossil data from the former Soviet Union and Mongolia, J. Biogeogr., 25, 1029-1054, 1998.

Tarasov, P. E., Guiot, J., Cheddadi, R., Andreev, A. A., Bezusko, L. G., Blyakharchuk, T. A., Dorofeyuk, N. I., Filimonova, L. V., Volkova, V. S., and Zernitskaya, V. P.: Climate in northern Eurasia 6000 years ago reconstructed from pollen data, Earth Planet. Sc. Lett., 171, 635-645, 1999a.

Tarasov, P. E., Peyron, O., Guiot, J., Brewer, S., Volkova, V. S., Bezusko, L. G., Dorofeyuk, N. I., Kvavadze, E. V., Osipova, I. M., and Panova, N. K.: Last Glacial Maximum climate of the Former Soviet Union and Mongolia reconstructed from pollen and plant macrofossil data. Clim. Dynam., 15, 227-240, $1999 \mathrm{~b}$.

Tarasov, P. E., Granoszewski, W., Bezrukova, E. V., Brewer, S., Nita, M., Abzaeva, A. A., and Oberhänsli, H.: Quantitative reconstruction of the Last Interglacial vegetation and climate based on the pollen record from Lake Baikal, Russia, Clim. Dynam., 25, 625-637, 2005.

Tarasov, P. E., Williams J. W., Andreev, A. A., Nakagawa, T., Bezrukova, E. V., Herzschuh, U., Igarashi, Y., Müller, S., Werner, 
K., and Zheng, Z.: Satellite- and pollen-based quantitative woody cover reconstructions for northern Asia: Verification and application to late-Quaternary pollen data, Earth Planet. Sc Lett., 264, 284-298, 2007.

Texier, D., de Noblet, N., Harrison, S. P., Haxeltine, A., Jolly, D., Joussaume, S., Laarif, F., Prentice, I. C., and Tarasov, P.: Quantifying the role of biosphere-atmosphere feedbacks in climate change: coupled model simulations for 6000 years BP and comparison with palaeodata for northern Eurasia and northern Africa, Clim. Dynam., 13, 865-882, 1997.
Velichko, A. A., Andreev, A. A., and Klimanov, V. A.: Climate and vegetation dynamics in the tundra and forest zone during the Late Glacial and Holocene, Quatern. Int., 41/42, 71-96, 1997.

Velichko, A. A., Catto, N., Drenova, A. N., Klimanov, V. A., Kremenetski, K. V., and Nechaev, V. P.: Climate changes in East Europe and Siberia at the Late Glacial-Holocene transition, Quatern. Int., 91, 75-99, 2002.

Walter, H.: Die Vegetation Osteuropas, Nord-und Zentralasiens, Gustav-Fischer-Verlag, Stuttgart, Germany, 462 pp., 1974. 